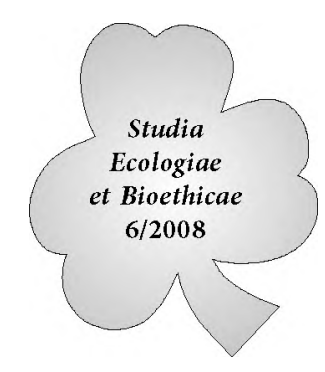

\title{
Wiedza dotycząca zrównoważonego rozwoju wśród młodzieży licealnej na podstawie badań pilotażowych
}

\begin{abstract}
Wstęp
Zrównoważony rozwój jest aktualnie istotnym wyzwaniem dla kształtowania świadomości nie tylko danych grup społecznych, lecz równie w szerszym rozumieniu, ogółu obywateli. Podejmując tę problematykę należy zwrócić szczególną uwagę na rolę edukacji w propagowaniu idei odpowiedzialności za środowisko naturalne i tym samym ekorozwoju. Szczególnie ważnym elementem kształcenia w myśl zasad edukacji prośrodowiskowej jest podjęcie wszelkich działań w placówkach szkolnych, których celem jest stymulowanie świadomości środowiskowej młodzieży, a także przygotowanie kadry pedagogicznej do wdrażania szeregu metod i strategii pozwalających na uzyskanie jak najlepszych wyników podczas edukowania młodego pokolenia.

Należy podjąć odpowiednie przedsięwzięcia w celu wspomagania edukacji w kształtowaniu wartości i pozytywnych postaw dotyczących realizacji VI Programu Środowiskowej Polityki Unijnej, a także wyeksponować nośną ideę tego programu: „Nasza przyszłość zależy od naszego wyboru”. ${ }^{1}$

Pojęcie zrównoważonego rozwoju pochodzi pierwotnie z leśnictwa, a stworzone zostało przez Hansa Carla von Carlowitza. Oznaczało ono pierwotnie sposób gospodarowania lasem polegający na tym, że wycina się tylko tyle drzew, ile może w to miejsce urosnąć, tak by las nigdy nie został zlikwidowany, by mógł się zawsze odbudować. ${ }^{2}$

Obecnie jednak definicja zrównoważonego rozwoju nie określa się jedynie do leśnictwa, została bowiem przejęta przez ruch ekologiczny w latach osiemdziesiątych i interpretowana jest w szerszym zakresie, jako świadomość środowiskowa i odpowiedzialność za stan zasobów naturalnych globu.
\end{abstract}

1 Cichy D. 2005: Edukacja środowiskowa wzmocnieniem zrównoważonego rozwoju. Instytut Badań Edukacyjnych. Wyższa Szkoła Pedagogiczna ZNP, Warszawa s. 5.

2 http://pl.wikipedia.org/wiki/Zr\%C3\%B3wnowa\%C5\%BCony_rozw\%C3\%B3j 27 lutego 2007. 
Zrównoważony rozwój jest zatem pojęciem bardzo szerokim, obejmującym w swoim zakresie szereg działań prowadzących do poszanowania środowiska naturalnego, polegających na racjonalnym gospodarowaniu jego zasobami. Dotyczy on wielu aspektów życia i sięga do różnorodnych dziedzin naukowych łącząc je pod jednym hasłem. Wiele pokrewnych terminów zawiera w sobie zagadnienia dotyczące zrównoważonego rozwoju i nawiązuje do jego idei. Jednym z nich jest pojęcie ekorozwoju, będące synonimem podanego terminu.

Ekorozwój najkrócej określić można jako kompromis pomiędzy potrzebami zachowania środowiska przyrodniczego, potrzebami gospodarki oraz potrzebami społecznymi. Ekorozwój obejmuje min.:

- rozsądne, a przez to długotrwałe wykorzystywanie odnawialnych zasobów przyrody,

- eksploatację nieodnawialnych źródeł energii z maksymalną efektywnością,

- utrzymywanie stabilności procesów ekologicznych i ekosystemów,

- ochronę różnorodności genetycznej,

- ogólnie pojętą ochronę przyrody,

- zachowanie i polepszenie stanu zdrowia ludzi, bezpieczeństwa pracy, edukacji i dobrobytu,

- wspieranie rozwoju upraw energetycznych.

Zrównoważony rozwój oznacza, że wzrost gospodarczy prowadzi do zwiększania spójności społecznej (w tym m.in. zmniejszania rozwarstwienia społecznego, wyrównywania szans, przeciwdziałania marginalizacji i dyskryminacji) oraz podnoszenia jakości środowiska naturalnego poprzez min. ograniczanie szkodliwego wpływu produkcji i konsumpcji na stan środowiska, ochronę zasobów przyrodniczych.

Leży on w polu zainteresowań wielu organizacji międzynarodowych. Należą do nich min. Program Narodów Zjednoczonych ds. Ochrony Środowiska, instytucje Unii Europejskiej (Parlament Europejski, Komisja Europejska, Europejski Komitet Ekonomiczno-Społeczny).

Do najważniejszych dokumentów prawno-międzynarodowych ujmujących problematykę zrównoważonego rozwoju należą: Agenda 21, Konwencja o Dostępie do Informacji, Udziale Społeczeństwa w Podejmowaniu Decyzji oraz Dostępie do Sprawiedliwości w Sprawach Dotyczących Środowiska. W Polsce zasada zrównoważonego rozwoju zyskała rangę konstytucyjną - została zapisana w art. 5 konstytucji RP.

Ogół procesu kształcenia dotyczący wiadomości zawierających idee prośrodowiskowe i ekorozwoju nazywamy edukacją środowiskową, która nie bez powodu odnosi się do założeń zrównoważonego rozwoju. Jest ona ważnym ogniwem w procesie kształcenia i odgrywa kluczową rolę w kształtowaniu postaw i świadomości nie tylko młodzieży szkolnej, lecz również całego społeczeństwa. 
Zdefiniujmy zatem podane pojęcie.

Edukacja środowiskowa - wyrażenie to, coraz powszechniej używane w szkolnictwie, oznacza to wszystko, co niesie w swojej treści wyrażenie: edukacja ekologiczna i edukacja sozologiczna oraz pewne aspekty samego terminu szeroko rozumianego środowiska. Dlatego edukacja środowiskowa zawiera w swojej treści następujące aspekty: biologiczny, abiotyczny, sozologiczny i społeczny. Zatem w tak rozumianej edukacji środowiskowej należy uwzględnić, zarówno w procesie nauczania, jak i wychowania, podstawową informację dotyczącą żywych systemów prostych i złożonych, elementów abiotycznych środowiska, sposobów i środków ochrony wszystkich elementów środowiskowych oraz znaczenia środowiska społecznego dla całego procesu edukacji środowiskowej. W edukacji ekologicznej bardzo ważną rolę mają tak zwane nauki ekologiczne, które dostarczają nam podstawowej informacji naukowej z wielu ważnych obszarów wchodzących w istotną strukturę środowiska. ${ }^{3}$

W kontekście idei zrównoważonego rozwoju istotne jest ustalenie, w jakim stopniu na zajęciach edukacyjnych wprowadzane są zagadnienia $\mathrm{z}$ nim związane, jak również zbadanie, jaki wpływ ma dana tematyka na kształtowanie świadomości prośrodowiskowej młodego człowieka. W tym celu przeprowadzono badania wśród 130 uczniów klas I, II i III - I LO im. S. Żeromskiego w Kielcach.

Wśród respondentów przeważającą grupę stanowiły dziewczęta

Tab. 1. Dane o uczniach

\begin{tabular}{|c|c|c|c|c|c|}
\hline pleć & Liczba ankietowanych & $\%$ & Klasy I & Klasy II & Klasy III \\
\hline Dziewczęta & 103 & 79,2 & 60 & 43 & 27 \\
\hline Chłopcy & 27 & 20,8 & & $33,1 \%$ & $20,8 \%$ \\
\hline Razem / \% & 130 & $100 \%$ & $46,1 \%$ & 3 \\
\hline
\end{tabular}

DoŁĘGA J. M. 2005: Znaczenie podstaw moralnych spoleczeństwa we wdrażaniu zrównoważonego rozwoju [w:] Edukacja środowiskowa wzmocnieniem zrównoważonego rozwoju. Red. D. Cichy Instytut Badań Edukacyjnych. Wyższa Szkola Pedagogiczna ZNP, Warszawa s. 11. 
Wykres 1. Dane o uczniach

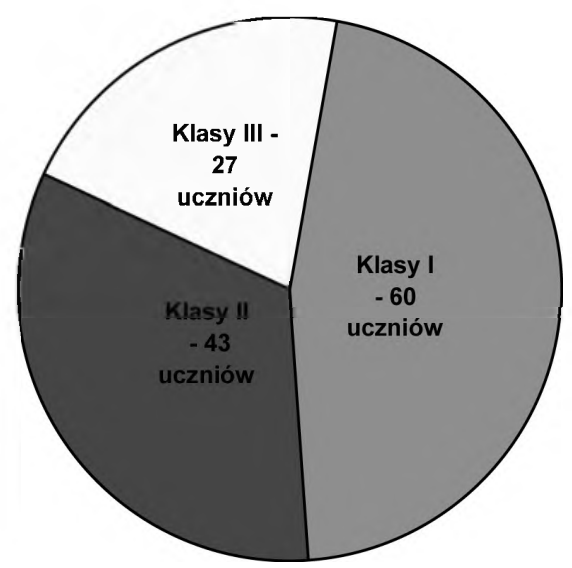

W pierwszym pytaniu ankiety poproszono uczniów o wyjaśnienie terminu „rozwój zrównoważony”. Aż 82 uczniów (63 \%) nie udzieliło w ogóle odpowiedzi na to pytanie, gdyż jeszcze nie uzyskali w swojej edukacji szkolnej żadnych informacji związanych $\mathrm{z}$ tym pojęciem. Poniżej przedstawiono wybrane prawidłowe odpowiedzi:

- „rozwój zrównoważony to umiejętne i racjonalne korzystanie z zasobów przyrody $w$ celu pozostawienia dóbr jakie daje nam środowisko naturalne młodszym pokoleniom",

- „rozwój, który propaguje ograniczenie ubóstwa i konfliktów pomiędzy bogatymi i biednymi krajami nie szkodzac przy tym środowisku",

- „jest to racjonalna gospodarka zasobami ziemi kontrolowanego rozwoju gospodarczego, sprawiedliwego podziału korzyści z niego wynikajacych, oraz rozwoju społecznego równocześnie z ochroną środowiska naturalnego",

- „rozwój, który zapewnia wzrost technologiczny, gospodarczy, zwiększenie ilości wykonanych dóbr dla człowieka z jednoczesną dbałością o środowisko naturalne”,

- „rozwój zrównoważony to taki, który umożliwia rozwój gospodarczy kraju, ale jednocześnie nie powoduje dużego zagrożenia dla środowiska”,

- „rozwój mający zapewnić skuteczną ochronę środowiska i racjonalną gospodarkę zasobami naturalnymi, wzrostu podziału korzyści z niego wynikających, tak aby wszystko zachowało równowage",

- „to działania polegające na rozwoju cywilizacji w harmonii z rozwojem środowiska i przyrody, tak aby wpływ człowieka na środowisko był zrównoważony i nie zagrażał mu",

- „ograniczenie ubóstwa i konfliktów między krajami biednymi i bogatymi, tak by nie szkodzić środowisku", 
— „rozwój zrównoważony to taki, który umożliwia rozwój gospodarczy kraju, ale jednocześnie nie zagraża i nie niszczy środowiska naturalnego",

- „polega na umiejetnym i racjonalnym korzystaniu z zasobów przyrody w celu zostawienia dóbr jakie daje nam środowisko naturalne młodszym pokoleniom”,

- „działania mające na celu wyrównanie poziomu życia między krajami biednymi i bogatymi, połączone z zaprzestaniem rabunkowej eksploatacji zasobów naturalnych",

- „rozwój zrównoważony ma na celu zapobieganie biedzie, ubóstwu, chorobom cywilizacyjnym, nędzy przy jednoczesnym dbaniu o świat roślin jak i zwierząt, zapobieganiu zanieczyszczeniu środowiska".

Ci którzy prawidłowo zdefiniowali pojęcie „rozwoju zrównoważonego” mieli również określić jaką wartość stanowi on dla nich i ich najbliższych, uzyskano następujące odpowiedzi:

- „Jest on bardzo ważny i staramy się lokalnie działać na rzecz tego rozwoju np. działając w stowarzyszeniu społeczno-kulturalnym „Razem” i różnych akcjach ekologiczno-społecznych",

- „Myślę, że jest to bardzo indywidualna sprawa dla każdej jednostki i każdy decyduje o jej wartości",

- „Rozwój zrównoważony jest dla mnie ważny, gdyż od niego zależy, czy będę żył w świecie pokoju i czystości, czy też w świecie zdegradowanym i antagonistycznym",

- „Ważne jest, aby dbać o środowisko naturalne, poprawę jego stanu, rozwój metod ochrony przyrody, gdyż za kilkadziesiąt lat następne pokolenia będą korzystały z naszego dorobku",

- „Rozwój zrównoważony stanowi dla nas swoistą „drogę" ku lepszej przyszłości środowiska, jego rządnej eksploatacji i dzięki temu jego bardziej owocnych zasobów",

- „Rozwój zrównoważony stanowi dla mnie dużą wartość, gdyż żyjąc w społeczeństwie, obcując z naturą i środowiskiem chciałabym, aby to co mnie otacza nie było zniszczone, żeby wszystko było racjonalnie zarządzane",

- „Uważam, że rozwój ten jest bardzo potrzebny, ponieważ na świecie są ludzie potrzebujący, biedni i bezdomni. Odrobina dobrej organizacji często może pomóc nam samym",

- „Rozwój zrównoważony jest zarówno dla mnie jak i mojej rodziny bardzo ważny. Może on dotyczyć świadomości, orientacji w świecie w którym żyjemy. Jeśli będziemy zdawać sobie sprawę z zagrożeń jakie mają dziś miejsce, na pewno będziemy mogli wiele zdziałać, aby to zmienić",

- „Każdy chce zadbać o rozwój zrównoważony, lecz nie każdy potrafi to wnieść w życie. Moi najbliżsi ocenią rozwój zrównoważony pozytywie”, 
Następnie zapytano uczniów, co ich zdaniem stanowi największe zagrożenie dla środowiska przyrodniczego w Polsce i na świecie. W tym wypadku wszyscy respondenci udzielali trafnych i często wyczerpujących odpowiedzi, co świadczy o dość wysokim poziomie wiadomości z zakresu podstawowych zagadnień ekologii. Oto poniżej kilka przykładowych odpowiedzi:

- "największym zagrożeniem sa wszelkie zanieczyszczenia powietrza pochodzace z fabryk, spaliny samochodowe itd. Wplywajq negatywnie na zdrowie człowieka, powodują kwaśne deszcze, przyczyniajq̨ się do wyginięcia wielu organizmów zwierzęcych i roślinnych",

- „nieodpowiednia segregacja odpadów lub brak jakichkolwiek działań zbliżonych do recyklingu, odpady porzucone np. w lasach mogą stwarzać zagrożenie dla atmosfery, mogą być siedliskiem bakterii, których rozmieszczenie prowadzić może nawet do epidemii”,

- „moim zdaniem największe zagrożenie dla środowiska przyrodniczego w Polsce i na świecie mają duże ilości fabryk i firm przemysłowych, bezmyślność ludzka (wyrzucanie śmieci do lasu, tworzenie dzikich wysypisk śmieci czy też odprowadzanie ścieków do rzek)",

- "zagrożenie dla środowiska przyrodniczego w Polsce i na świecie stanowi w dużym stopniu dziura ozonowa. Wpływa ona na zmiany klimatu, co może znacznie zaszkodzić środowisku roślin i zwierząt. Niektóre gatunki są zagrożone wyginięciem",

- „według mnie największym zagrożeniem jest wycinanie lasów równikowych co powoduje ubożenie fauny i flory naszej planety, wzrost ilości gazów cieplarnianych np. $\mathrm{CO}_{2}, \mathrm{CH}_{4}$ do atmosfery, co w konsekwencji przyczynia się do nasilenia efektu cieplarnianego i ocieplenia klimatu co możemy obserwować obecnie", - „największym zagrożeniem są katastrofy ekologiczne, które w większości powstają przez nadmierną ingerencję człowieka w przyrodę np. katastrofy tankowców przewodzących ropę, wybuchy reaktorów w elektrowni atomowej",

- „brak świadomości zagrożeń płynących z nierozsądnego niszczenia naszej planety jest największym dla niej zagrożeniem. \o, że ludzie nie zdają sobie sprawy jak destrukcyjny wpływ mają na stan środowiska przyrodniczego i nie starają się nic dla jego ochrony przedsięwziąć”.

W kolejnym pytaniu poproszono uczniów, by wskazali sposoby, jakie można wykorzystać celem uświadomienia społeczeństwu powagi problemów związanych z degradacją przyrody. Respondenci udzielali wyczerpujących odpowiedzi na pytanie podając kilka przykładów. Kilka wybranych zamieszczono poniżej: - „organizować akcje popierające ekologię, zaprzestać działań prowadzących do niszczenia przyrody, edukacja dzieci już od szkoły podstawowej jak powinny szanować przyrodą", 
- „Zwiększenie akcji na rzecz ochrony przyrody przy włączeniu w nie większej ilości osób i zachęcanie ich do działania w nich",

- „wprowadzać drobne nagrody albo jakieś ulgi podatkowe np. za segregowanie śmieci, zachowywanie czystości w miejscu swojego zamieszkania, a w wyniku wszelkiej działalności wpływającej szkodliwie na środowisko zastosować drakońskie kary",

- „pokazanie społeczeństwu zanieczyszczonych zakątków świata jeszcze istniejących, którym grozi zagłada, a także tych pięknych (np. kraj kwitnącej wiśni, Holandia), które mogą być zdegradowane w przyszłości",

- „organizowanie festynów, koncertów pod odpowiednim hasłem, na rzecz ochrony środowiska",

- „ukazanie na zajęciach w szkole, w pracy, miejscach publicznych krótkich filmów edukacyjnych o nieodwracalnych zmianach zachodzących w przyrodzie", - „organizowanie imprez w plenerze, a także propagowanie postawy przyjaznej środowisku”,

- „rząd powinien poważnie potraktować tę kwestię i wydać odpowiednie rozporządzenia oraz podjąć dyskusję na temat ochrony środowiska”,

Z powyższych wypowiedzi uczniów wynika, iż mają różne koncepcje by w możliwie prosty sposób poprawić spojrzenie ludzi na problemy związane z przyrodą.

W jednym z pytań uczniowie mieli za zadanie wskazać ich zdaniem największą katastrofę ekologiczną, jaka zdarzyła się w ostatnich kilkudziesięciu latach.

Z odpowiedzi wynika iż, dla 74,5\% uczniów najgroźniejszy był wybuch reaktora w elektrowni jądrowej w Czarnobylu, dla 15,6\% awaria tankowca na Morzu Płn., a dla 9,8\% negatywnie na środowisko wpływały inne katastrofy - tutaj wymieniano pożary lasów w Brazylii, podpalenie szybów naftowych w czasie wojny w Zatoce Perskiej, wyciek herbicydów u wybrzeża stanu Missouri. Zastanawiające jest dlaczego aż 21,5\% nie przytoczyło żadnego przykładu katastrofy.

Tab. 2. Najgroźniejsze katastrofy ekologiczne w ocenie uczniów, które wydarzyly się w ostatnich kilkudziesieciu latach

\begin{tabular}{|l|c|c|}
\hline \multicolumn{1}{|c|}{ Katastrofa ekologiczna } & Liczba ankietowanych & Procent \\
\hline Czarnobyl & 76 & $58,5 \%$ \\
\hline Wybuch tankowca & 16 & $12,3 \%$ \\
\hline Inne & 10 & $7,7 \%$ \\
\hline Nie podano żadnych przykładów & 28 & 21,5 \\
\hline Razem & 130 & $100 \%$ \\
\hline
\end{tabular}


Wykres 2. Najgroźniejsze katastrofy ekologiczne

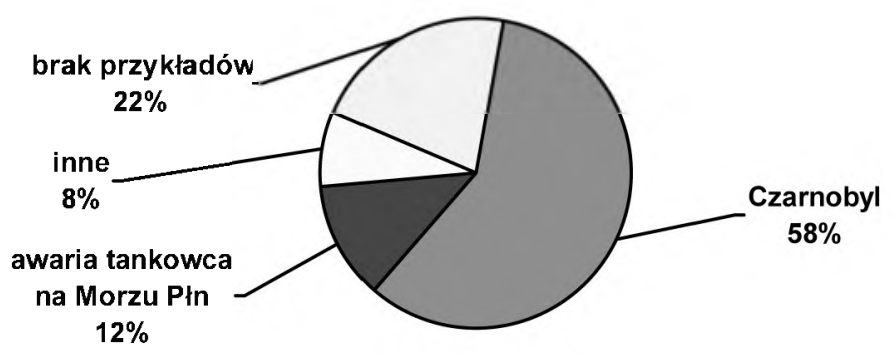

Ponizej zacytowano kilka przykładowych odpowiedzi uczniów:

- „Najgroźniejsza w skutkach katastrofa ekologiczna miała miejsce w Czarnobylu, ponieważ skutki katastrofy były odczuwalne długo po, a większość ludzi zachorowało na raka",

- „Czarnobyl w 1986 r. Skutki wybuchu reaktora jądrowego są widoczne do dzisiaj, nie tylko w pobliżu tej miejscowości, ale i na terenach od niej odległych", - „Poważną katastrofą ostatnich lat była awaria tankowca na Morzu Płn. Ogromny wyciek ropy spowodował skażenie wielu milionów $\mathrm{m}^{3}$ wody oraz śmierć fauny i flory morskiej”,

- „Katastrofa elektrowni jądrowej w Czarnobylu. Była to katastrofa ekologiczna na dużą skalę. W jej wyniku zmarło wiele osób, a wielu ludzi do dziś cierpi na choroby popromienne".

Zapytano również uczniów, z jakich źródeł wiedzy czerpią informacje na temat rozwoju zrównoważonego oraz stanu środowiska przyrodniczego. Wyniki zamieszczono w poniższej tabeli i na wykresie:

Tab. 3. Źródla informacji wykorzystywane przez uczniów

\begin{tabular}{|c|c|c|}
\hline Wariant odpowiedzi & Liczba ankietowanych & Procent $^{*}$ \\
\hline Internet & 82 & 63,1 \\
\hline Delewizja & 87 & 66,9 \\
\hline Radio & 37 & 28,5 \\
\hline prasa codzienna & 32 & 24,6 \\
\hline prasa ekologiczna & 16 & 12,3 \\
\hline
\end{tabular}

* \% nie sumują się do 100; wybór wielokrotny. 
Wykres. 3. Źródta informacji wykorzystywane przez uczniów

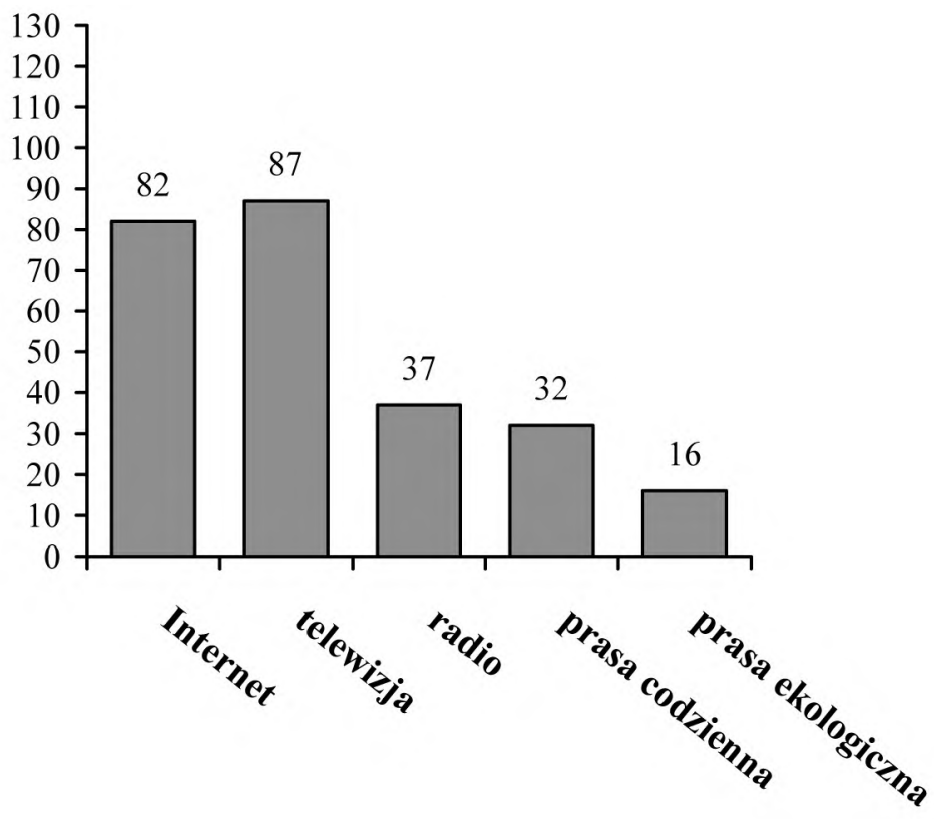

Jak wynika $z$ danych przedstawionych w tabeli i na wykresie, telewizja w $87 \%$ jest najbardziej dogodnym dla uczniów źródłem informacji na tematy dotyczące środowiska przyrodniczego.

W kolejnym zadaniu uczniowie mieli wymienić największe ich zdaniem problemy społeczne na świecie. Najczęściej wskazywanym był głód, następnie choroby cywilizacyjne, zanieczyszczenie środowiska, ubóstwo, wojny.

Tab. 4. Najczęściej wymieniane przez uczniów problemy społeczne

\begin{tabular}{|l|c|c|}
\hline \multicolumn{1}{|c|}{ Problem } & Ilość & Procent \\
\hline głód & 69 & 35 \\
\hline choroby cywilizacyjne & 39 & 19,8 \\
\hline zanieczyszczenie środowiska & 38 & 19,3 \\
\hline ubóstwo & 34 & 17,3 \\
\hline wojny & 17 & 8,6 \\
\hline Razem & 197 & $100 \%$ \\
\hline
\end{tabular}


Wykres 4. Najczęściej wymieniane przez uczniów problemy społeczne

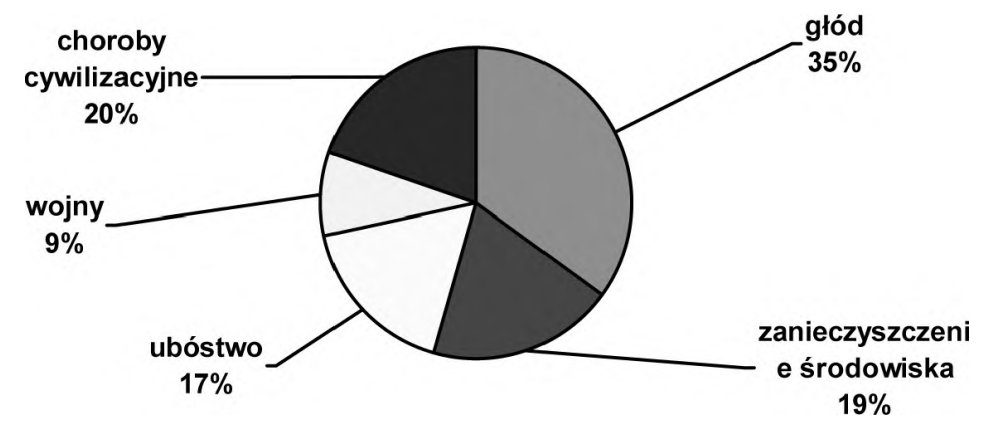

Następne pytanie dotyczyło oceny uczniów stanu środowiska w kraju i na świecie. Wyniki przedstawiono w poniższej tabeli.

Tab. 5 Ocena stanu środowiska wg uczniów

\begin{tabular}{|c|c|c|c|c|c|}
\hline \multirow[b]{2}{*}{ klasy } & \multirow[b]{2}{*}{ Stan środowiska } & \multicolumn{2}{|c|}{ Kraj } & \multicolumn{2}{|c|}{ Swiat } \\
\hline & & $\begin{array}{c}\text { Liczba } \\
\text { ankietowanych }\end{array}$ & Procent & $\begin{array}{c}\text { Liczba } \\
\text { ankietowanych }\end{array}$ & Procent \\
\hline \multirow{6}{*}{ Klasy I } & bardzo dobry & 1 & $1,66 \%$ & & \\
\hline & dobry & 16 & $26,66 \%$ & 2 & $3,33 \%$ \\
\hline & katastrofalny & 4 & $6,66 \%$ & 15 & $25 \%$ \\
\hline & zagrożony & 24 & $40 \%$ & 32 & $53,33 \%$ \\
\hline & trudno powiedzieć & 13 & $21,66 \%$ & 10 & $16,66 \%$ \\
\hline & nie mam zdania & 2 & $3,33 \%$ & 1 & $1,66 \%$ \\
\hline \multirow{7}{*}{ Klasy II } & razem & 60 & $100 \%$ & 60 & $100 \%$ \\
\hline & bardzo dobry & & & & \\
\hline & dobry & 11 & $25,58 \%$ & 2 & $4,65 \%$ \\
\hline & katastrofalny & 7 & $16,27 \%$ & 9 & $20,93 \%$ \\
\hline & zagrożony & 16 & $37,20 \%$ & 26 & $60,46 \%$ \\
\hline & trudno powiedzieć & 7 & $16,27 \%$ & 4 & $9,3 \%$ \\
\hline & nie mam zdania & 2 & $4,65 \%$ & 2 & $4,65 \%$ \\
\hline \multirow{8}{*}{ Klasy III } & razem & 43 & $100 \%$ & 43 & $100 \%$ \\
\hline & bardzo dobry & & & & \\
\hline & dobry & 10 & $37,03 \%$ & 2 & $7,4 \%$ \\
\hline & katastrofalny & & & 1 & $3,7 \%$ \\
\hline & zagrożony & 15 & $55,55 \%$ & 16 & $59,25 \%$ \\
\hline & trudno powiedzieć & 1 & $3,70 \%$ & 7 & $25,92 \%$ \\
\hline & nie mam zdania & 1 & $3,70 \%$ & 1 & $3,7 \%$ \\
\hline & razem & 27 & $100 \%$ & 27 & $100 \%$ \\
\hline
\end{tabular}


Na podstawie powyższych wyników zamieszczonych w tabeli można jednoznacznie stwierdzić iż uczniowie wszystkich klas najczęściej oceniali stan środowiska jako zagrożony zarówno w kraju jak i na świecie. Uczniowie klas I i II nierzadko oceniali go jako katastrofalny.

Wykres. 5. Ocena stanu środowiska w kraju w opinii uczniów wszystkich klas

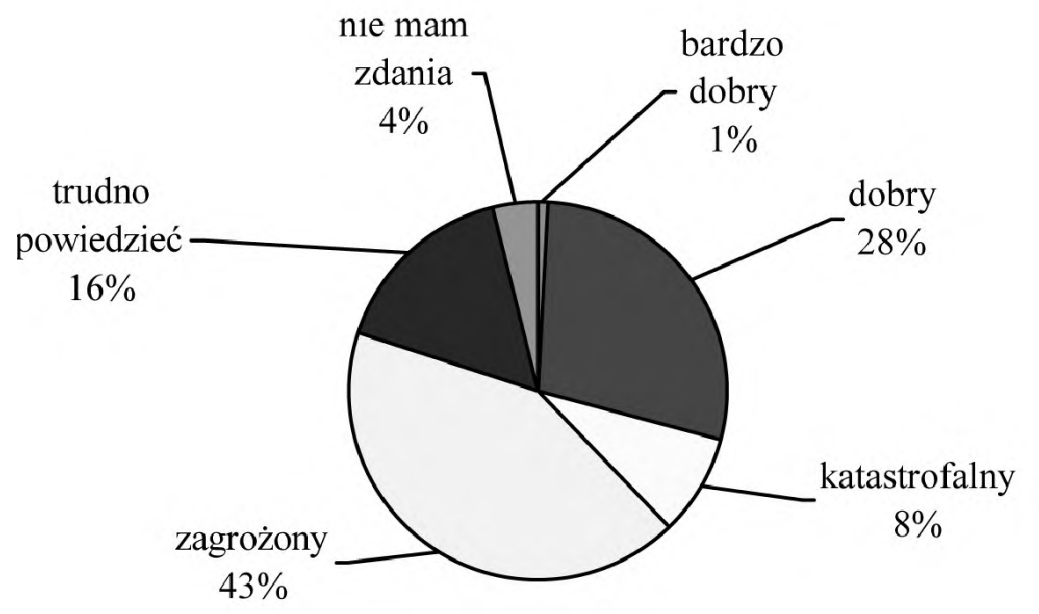

Wykres. 6. Ocena stanu środowiska na świecie w opinii uczniów wszystkich klas

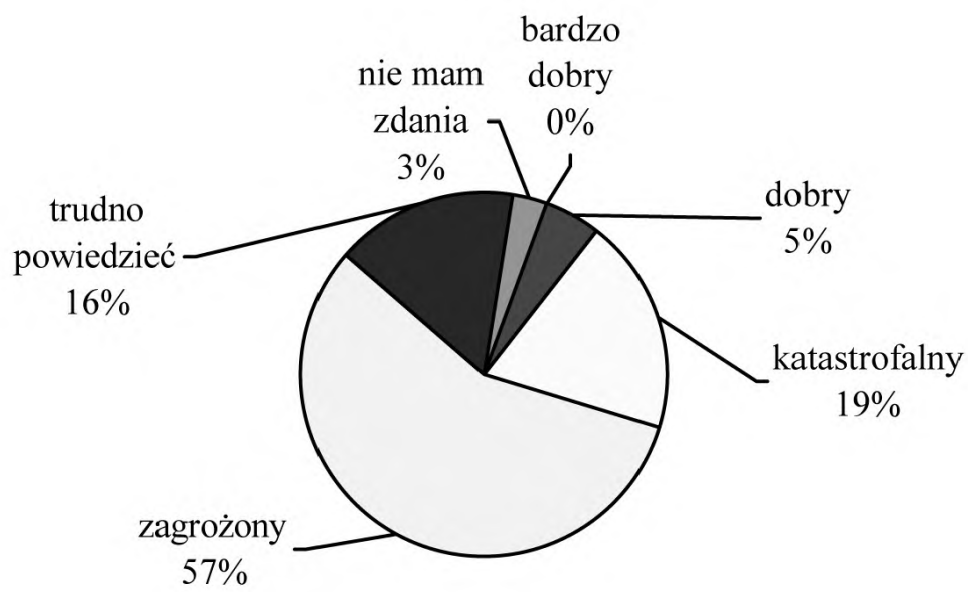

Jednak po wprowadzeniu danych do uproszczonej tabeli okazuje się, że znacznie lepiej oceniają uczniowie stan środowiska w kraju niż na świecie. 
Tab. 6. Porównanie oceny uczniów stanu środowiska w kraju i na świecie. (Zauważalne różnice zostaly wyszczególnione

\begin{tabular}{|l|c|c|}
\hline \multirow{2}{*}{ Ocena stanu środowiska } & \multicolumn{2}{|c|}{ Procent wskazań } \\
\cline { 2 - 3 } & W kraju & Na świecie \\
\hline bardzo dobry & 1 & 0 \\
\hline dobry & 28 & 5 \\
\hline katastrofalny & 8 & 19 \\
\hline zagrożony & 42 & 57 \\
\hline trudno powiedzieć & 16 & 16 \\
\hline nie mam zdania & 4 & 3 \\
\hline
\end{tabular}

W jednym z kolejnych zadań ankiety poproszono uczniów o napisanie własnej interpretacji sformułowania: „Myśl globalnie-działaj lokalnie!” Wszyscy badani respondenci rozumieją sens tego sformułowania. Poniżej przedstawiono wybrane odpowiedzi.

- „należy myśleć o ochronie środowiska i organizować różne akcje; edukować społeczeństwo na świecie, jednak wszystkie działania każdy z nas powinien podejmować indywidualnie, aby w jego najbliższym otoczeniu panował „porządek",

- „oznacza to, że myśląc o przyszłości Ziemi musimy działać w swoim najbliższym otoczeniu, wprawdzie sami nie poprawimy jakości całego świata, ale jeśli każdy wokół siebie będzie dbał o przyrodę, wtedy świat nie będzie zagrożony", - „trzeba myśleć co dobrego można zrobić nie tylko dla swojego miasta czy kraju, ale też dla całego świata. Nie jest to latwe, ale gdy samemu się zacznie, inni wezmą z nas przykład. Można zacząć np. od zmniejszenia ilości różnych zanieczyszczeń, dbać o porządek wokół siebie",

- „działania lokalne są początkiem ochrony świata. Najpierw trzeba zacząć od małych obszarów, by zapobiec ich degradowaniu. W ten sposób możemy przyczynić się do ochrony świata",

- „sformułowanie to zachęca, by zainteresować się problemami globalnymi-takimi, które dotyczą całego świata. Jednym z takich problemów jest zagrożenie środowiska. Działaj lokalnie sugeruje, aby starać się polepszać stan całego świata, zaczynając pracę u podstaw we własnym regionie".

Podsumowując powyższe wypowiedzi uczniów można stwierdzić iż, dziś dużo mówi się o ochronie środowiska. Słyszymy o tym wszędzie. Jednak, czy zrobimy cokolwiek, by rzeczywiście je chronić? Słowa „myśl globalnie - działaj lokalnie" dają nam do zrozumienia, że aby ratować środowisko przyrodnicze powinniśmy zacząć od siebie, własnego otoczenia. 
W następnym pytaniu uczniowie mieli wskazać największe zagrożenia środowiska w swoim miejscu zamieszkania. Ich odpowiedzi były zwykle trafne i wyczerpujące.

- „zagrożeniami tymi są masowe wyrzucanie śmieci do lasów i innych miejsc, które nie sa przeznaczone do tego celu, duża ilość spalin, zanieczyszczone wody. Sposobami zaradczymi może być korzystanie z alternatywnego transportu (rower, komunikacja miejską), zamontowanie większej ilości koszy na śmieci, a także specjalnych pojemników na segregowane odpady, poważne kary dla ludzi zanieczyszczających środowisko",

- „mieszkam w okręu zurbanizowanym, w którym wykorzystywane jest mnóstwo energii. Pochodzi ona niestety najczęściej z elektrowni węglowych, które w dużym stopniu zanieczyszczaja środowisko. Powinno się je zamienić na bardziej ekologiczne źródła energii",

- „zakład wapienniczy w mojej miejscowości - Bukowie - emituje duże ilości pyłu, jest wiadomo, że zaniedbuje sie właczenie filtrów ochronnych, jednak $\dot{z} a d n e$ lokalne działania temu nie zapobiegaja",

- „myślę, że chłodnia kielecka produkujac niezbędne do jej funkcjonowania freony bardzo szkodzi naszemu miastu. Oprócz tego zanieczyszczenie powietrza przez np. samochody, w niektórych miejscach jest bardzo du̇e. Środkiem zaradczym może być wybudowanie obwodnic, które ograniczylyby przejazd wielu samochodów przez Kielce",

— „w mojej miejscowości jest rezerwat, a obok niego budynek firmy, Techmłot’. Wszystkie ścieki z fabryki splywaja do pobliskiego zalewu, który jest objęty ochrona. Żyja w nim bardzo rzadkie gatunki roślin i zwierząt. Obok niego jest las, który jest zanieczyszczony pylami z fabryki. W rezerwacie zyją nawet czarne bociany. Boję się, że jak tak dalej będzie zanieczyszczone środowisko moge już ich nie zobaczyć!",

— „do starych kopalni wapienia sa wywożone śmieci użytku codziennego: plastik, szkło, papiery, folia, gumy, papa dachowa itp. Powinno sie stosować kary za takie postępowanie i to bardzo duze, rzędu np. $5000 z t$, to powinno odstraszyć śmieciarzy".

$\mathrm{W}$ jednym $\mathrm{z}$ ostatnich pytań poproszono respondentów o wyrażenie opinii w sprawie wdrażania i realizacji w szkole zasad zrównoważonego rozwoju.

Tab. 7 (klasy $I-60$ osób)*

\begin{tabular}{|l|c|c|}
\hline \multicolumn{1}{|c|}{ Wariant odpowiedzi } & Liczba ankietowanych & Procent \\
\hline Są wdrażane & 6 & $10,7 \%$ \\
\hline Nie & 3 & $5,4 \%$ \\
\hline Nie wiem & 47 & $83,9 \%$ \\
\hline Razem & 56 & $100 \%$ \\
\hline
\end{tabular}

* liczba ankietowanych wynosi 56, gdyż 4 osoby nie odpowiedziały na to pytanie. 
Wykres 7. Opinia uczniów na temat wdrażania zasad zrównoważonego rozwoju (klasa I)

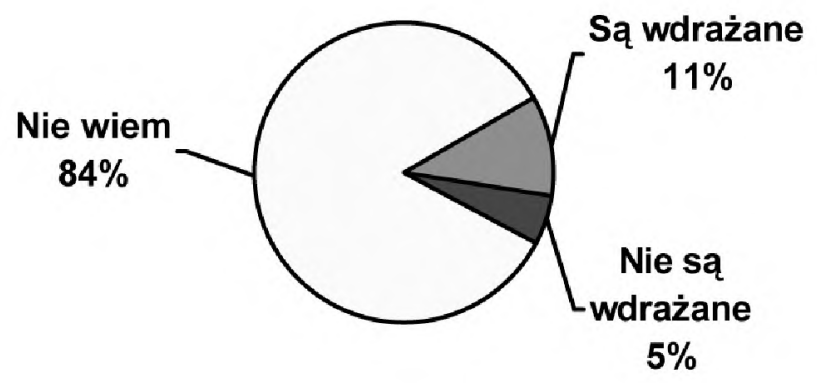

47 uczniów to jest $83,92 \%$ nie wie czy ich szkoła zajmuje się realizacją i wdrażaniem zasad zrównoważonego rozwoju. 6 osób 10,71\% jest zdania iż, szkoła wdraża zasady rozwoju, natomiast tylko 3 osoby (5,35\%) twierdzi, iż tak nie jest.

Tab. 8 (klasy II-43 osoby)*

\begin{tabular}{|l|c|c|}
\hline \multicolumn{1}{|c|}{ Wariant odpowiedzi } & Liczba ankietowanych & Procent \\
\hline Są wdrażane & 5 & $12,5 \%$ \\
\hline Nie & 5 & $12,5 \%$ \\
\hline Nie wiem & 30 & $75 \%$ \\
\hline Razem & 40 & $100 \%$ \\
\hline
\end{tabular}

* 3 osoby nie odpowiedziały na pytanie dlatego suma wynosi 40 .

Wykres 8. Opinia uczniów na temat wdrażania zasad zrównoważonego rozwoju (klasa II)

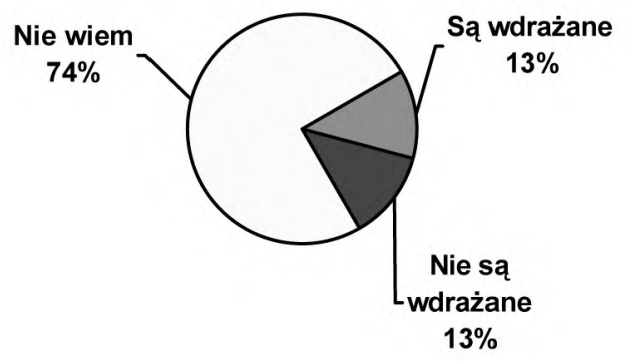

W klasach II sytuacja przedstawia się następująco. Również większość osób $30(75 \%)$ twierdzi, iż nie wiedzą czy ich szkoła zajmuje się wdrażaniem zasad zrównoważonego rozwoju, natomiast $12,5 \%$ ankietowanych jest zdania, że szkoła realizuje zasady rozwoju zrównoważonego i tyle samo uważa, że szkoła ich nie realizuje. 
Tab. 9. (klasy III-27 osób)

\begin{tabular}{|l|c|c|}
\hline Wariant odpowiedzi & Liczba ankietowanych & Procent \\
\hline Są wdrażane & 1 & $3,7 \%$ \\
\hline Nie & 5 & $18,5 \%$ \\
\hline Nie wiem & 21 & $77,8 \%$ \\
\hline Razem & 27 & $100 \%$ \\
\hline
\end{tabular}

Wykres 9. Opinia uczniów na temat wdrażania zasad zrównoważonego rozwoju (klasa III)

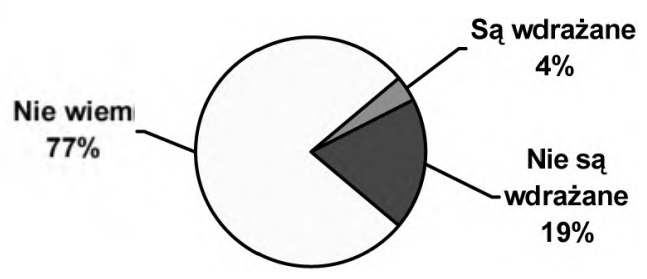

Uczniowie klas III w większości również nie wiedzą czy ich szkoła realizuje zasady zrównoważonego rozwoju $(21-77,8 \%)$. 18,5\% jest zdania, że nie, natomiast tylko 1 osoba to jest 3,7\% powiedziała, że szkoła zajmuje się wprowadzaniem w edukację zasad zrównoważonego rozwoju.

Niepokojące jest dlaczego tak duży procent ankietowanych nie wie czy szkoła wdraża i realizuje zasady zrównoważonego rozwoju.

Po przeanalizowaniu uzyskanych wyników badań $\mathrm{z}$ ankiety można stwierdzić, że zdecydowana większość uczniów nie potrafi zdefiniować terminu „rozwój zrównoważony”. Przyczyną tego jest fakt, że sprawy z nim związane nie wprowadzono na początku edukacji w szkole średniej, a dopiero w III klasie. Mimo braku podstawowych wiadomości z omawianego zakresu, to jednak respondenci wykazali się wysokim poziomem wiedzy z tematyki ściśle związanej z rozwojem zrównoważonym. Udzielali między innymi wyczerpujących odpowiedzi na temat największych zagrożeń dla środowiska przyrodniczego w Polsce, trafnie je wymieniając. Licealiści zdają sobie sprawę $z$ tego $w$ jak łatwy sposób można zaszkodzić środowisku i jak można wpłynąć na świadomość społeczeństwa by nie dopuścić do jego degradacji. Mentalność ludzi szkodzącą przyrodzie można zmienić przez organizowanie akcji popierających ekologię, zaprzestanie działań prowadzących do jej niszczenia, czy edukowanie dzieci już od szkoły podstawowej, jak powinny szanować przyrodę.

Rozpatrując klęski ekologiczne, jakie miały miejsce w ciągu ostatnich kilkudziesięciu lat, młodzież wskazała wybuch reaktora jądrowego w Czarno- 
bylu jako najpoważniejszą. Jednak wymienione inne przykłady świadczą i potwierdzają fakt, że młodzież dysponuje szeroką wiedzą z omawianego zakresu. Przedstawienie katastrof $\mathrm{w}$ różnej kolejności, sugeruje o ich różnej interpretacji i często względności omawianych skutków.

Jako najważniejsze źródło pozyskiwania informacji respondenci wskazali telewizję, jednak niewiele mniejszą popularnością cieszy się Internet. Wynika to $\mathrm{z}$ coraz łatwiejszego dostępu do niego (chociaż z pewnością jeszcze nie dla wszystkich) i aktywnej, a tym, samym skutecznej i szybszej formy, wyszukiwania w nim wiadomości.

Ze znanych problemów społeczeństwa na świecie, uczniowie wymieniali w kolejności: głód, choroby cywilizacyjne, zanieczyszczenie środowiska, ubóstwo i na końcu wojny. Jedną z metod zapobiegania wszystkich problemów powinien być apel do ludzi z prośbą o pomoc w organizacji akcji humanitarnych wspomagających ludzi potrzebujących i szanowania przyrody.

Jednoznacznie młodzież oceniła, że kraj jak i świat jest zagrożony pod względem stanu środowiska naturalnego, a sformułowanie „myśl globalnie - działaj lokalnie" jest prawidłowo interpretowane i trzeba mieć nadzieję, że będzie coraz częściej wprowadzane w praktykę.

\section{Zakończenie}

Podsumowując, należy wnioskować, iż uczniowie I LO w Kielcach są świadomi stanu środowiska przyrodniczego w kraju i na świecie. Potrafią wskazać ewentualne metody zapobiegania dalszej degradacji środowiska. Niestety w swojej edukacji szkolnej nie uzyskali jeszcze wystarczającej wiedzy odnośnie do rozwoju zrównoważonego; definicji samego pojęcia, 27 zasad Deklaracji z Rio de Janeiro, czy też nie zapoznali się z treścią „Agendy 21”. Wydaje się, że wiedza $\mathrm{z}$ tego zakresu jest chaotyczna i nieusystematyzowana, co trzeba wziąć pod uwagę w układaniu programów różnych przedmiotów i ścieżek.

\section{LI冈ERA囚URA}

Cichy D. 2005: Edukacja środowiskowa wzmocnieniem zrównoważonego rozwoju. Instytut Badań Edukacyjnych. Wyższa Szkoła Pedagogiczna ZNP, Warszawa, s. 5.

DoŁęGA J. M. 2005: Znaczenie podstaw moralnych spoleczeństwa we wdrażaniu zrównoważonego rozwoju [w:] Edukacja środowiskowa wzmocnieniem zrównoważonego rozwoju. Red. D Cichy Instytut Badań Edukacyjnych. Wyższa Szkoła Pedagogiczna ZNP, Warszawa, s. 11.

http://pl.wikipedia.org/wiki/Zr\%C3\%B3wnowa\%C5\%BCony_rozw\%C3\%B3j 27 lutego 2007 


\title{
The knowledge concerning the balanced development among the high school students based on the initial research
}

\author{
SUMMARY
}

The balanced development is at present the challenge for creating the awareness not only of the particular society, but also in the widest sense for the whole generation of the people. Undertaking such issues, the role of education during all stages of teaching, should be taken into consideration, especially, in the range of propagating the idea of responsibility for the natural environment with eco-development. It is a specially important element of teaching according to the principle of pro-environmental education to undertake all actions in the educational centers, which aim is to stimulate the environmental awareness of young people as well as to prepare the pedagogical staff to the realization of the wide range of methods and strategies that allow to get the best results during the process of educating young generation.

The appropriate undertakings should be realized in order to support the education in the process of introducing the right value system and positive attitudes towards realization of the sixth Environmental politics of the EU Programme.

With the connection to the carried on initial research associated with the knowledge about the balanced development among high school students, analysing the results of the questionnaires, the answer to the question whether students possess any kind of knowledge on balanced development was to be learned. 